\title{
O PARADIGMA DA VERDADE QUE PERPASSA AS METAFÍSICAS CLÁSSICA E MODERNA E DETERMINA AS DECISÕES JUDICIAIS
}

\author{
PARADIGM OF TRUTH DETERMINES THE METAPHYSICS \\ CLASSIC AND MODERN AND DETERMINE THE JUDGMENTS
}

\begin{abstract}
GABRIELLE TESSER GugeL
Mestranda em Direito Público pela UNISINOS. Bacharel em Direito pela Universidade de Caxias do Sul. Advogada.

Presidente da Associação Nacional dos Emigrados e Ex-emigrados das Américas e Austrália - Brasil.
\end{abstract}

gabitgugel@gmail.com

\section{RESUMO}

O presente texto objetiva a compreensão acerca de que modo o dualismo sujeito-objeto encontra-se presente nas decisões judiciais dos Tribunais. Como garantir a eficácia do Código de Processo Civil diante da consciência do magistrado e dos paradigmas aqui apontados? Demonstra-se que a filosofia da linguagem influencia a forma como as decisões são tomadas no Tribunal. Por isso objetiva-se abordar o pensamento desenvolvido na metafísica clássica e moderna. $\mathrm{Na}$ metafísica clássica a noção acerca da verdade encontrava-se nas coisas, ou seja, nos objetos, sendo de forte influência para a Escola da Exegese surgida na França e na Escola da Jurisprudência dos Conceitos elaborada da Alemanha. A ruptura ocorrida na metafísica moderna traz a filosofia da consciência e a noção de sujeito formulada por Descartes. O sujeito passa a ser o assujeitador das coisas, é nele que está a verdade, o conhecimento prévio. Sua influência está claramente presente na Escola da Jurisprudência dos Interesses. A metafísica moderna somente foi superada no campo da filosofia, com o giro linguístico. A metodologia utilizada será o método hermenêutico.

Palavras-chave: metafísica clássica; metafisica da consciência; objeto-sujeito.

\begin{abstract}
This paper aims at understanding how the subjectobject dualism is present in judgments of the Courts. How to ensure the effectiveness of the Code of Civil Procedure before the conscience of the magistrate and the paradigms highlighted here? Demonstrates that the philosophy of language influences how decisions are made in Court. So the objective is to address the thinking developed in classical metaphysics and modern. In classical metaphysics the notion of the truth found in the things, ie, the objects, being a strong influence for the School of Exegesis arose in France and in the School of Jurisprudence of the concepts developed in Germany. The rupture occurred in modern metaphysics brings the philosophy of consciousness and the notion of subject formulated by Descartes. The subject becomes the subjugated of things, is that it is the truth, the prior knowledge. His influence is clearly present in the School of Jurisprudence of Interests. The modern metaphysics was only surpassed in the field of philosophy, with the linguistic turn. The methodology used will be the hermeneutical method.
\end{abstract}

Keywords: classical metaphysics, the metaphysics consiência; object-subject;

\section{SUMÁRIO}

INTRODUÇÃO; 1 METAFÍSICA CLÁSSICA: A PARTIR DE CRÁTILO DISCUTE-SE A FILOSOFIA DA LINGUAGEM; 2 METAFÍSICA MODERNA: DO SUBJETIVISMO À DISCRICIONARIEDADE; CONCLUSÃO; REFERÊNCIAS 


\section{INTRODUÇÃO}

O presente texto tem por escopo analisar em que medida os paradigmas da metafísica clássica e moderna, baseadas no dualismo sujeito-objeto, formam a ideia de verdade no neopositivismo e consequentemente estão presentes nas decisões judiciais dos Tribunais. Como garantir a eficácia do Código de Processo Civil diante da consciência do magistrado e dos paradigmas aqui apontados?

Isso ocorre devido aos problemas de linguagem, pois os juristas estão diariamente envoltos com a linguagem, esta é necessária para que se possam articular os pensamentos, bem como expressar-se. As leis e normas jurídicas são textos que se relacionam à vida em sociedade. De modo que, a linguagem ao longo dos anos vem sendo estudada pela filosofia do Direito, tendo em vista que desde a antiguidade buscava-se saber o que era a verdade, ou seja, onde basear-se para poder decidir e como deveria ser tal decisão. Nesse contexto a metafísica tem por condão tratar de filosofia no Direito. Tal análise será desenvolvida a partir da matriz hermenêutica, por meio de filósofos e juristas que também trataram sobre o referido tema.

Em um primeiro momento contextualiza-se o início da filosofia da linguagem (1), partindo-se de Platão e de sua noção sobre a verdade, visto que para ele, esta se encontrava nas coisas, uma vez que as palavras e a linguagem podiam ser enganosas. Tanto ele quanto Aristóteles traçam suas teorias de maneira a rechaçar as ideias dos sofistas, pois não acreditavam que a linguagem deveria ser utilizada como melhor conviesse ao indivíduo. 0 que deveria ser buscado era a verdade. Para Aristóteles é através da essência das coisas que poderá dar sentido àquilo que se fala, ou a forma como o mundo se apresenta. Apresenta-se o entendimento contrário, o qual foi elaborado pelos estoicos, pois estes não comungavam que os objetos possuíssem essência, sendo que, seus textos serviram de base para que Saussure realizasse sua teoria acerca do signo. 0 pensamento dominante na metafísica clássica permaneceu durante a Idade Média, nesse período muitos dos textos gregos foram traduzidos para o cristianismo. Nesse período Santo Agostinho busca na interioridade a solução para a verdade, enquanto que Santo Tomás de Aquino sustenta na razão divina a noção de verdade. Em oposição as suas ideias surge o nominalismo de Guilherme de Ockham, que vai enfatizar a importância da linguagem. Posteriormente, apresenta-se a influência desse pensamento metafísico na Escola da Exegese surgida na França e na Escola da Jurisprudência dos Conceitos 
elaborada da Alemanha, onde apesar de tentarem dar uma resposta ao sistema positivista, não deixaram de importar os mesmos preceitos já presentes na Antiguidade.

Há então a ruptura trazida pela metafísica moderna (2) a partir da noção de sujeito formulada por Descartes, sendo o filósofo responsável pela criação do solipsismo cartesiano como consequência do argumento do cogito (penso, logo existo). Nesse período o contratualista Thomas Hobbes, defensor da tese que a sociedade civil resultaria de um contrato traz que a linguagem seria o instrumento fundamental para a formulação do Estado. Apresenta-se, ainda, a teoria de Immanuel Kant, na qual a linguagem possui um caráter acessório, visto que o conhecimento pertenceria ao indivíduo a priori. Por meio de Nietzsche ocorre uma ruptura paradigmática no pensamento, pois não concordando com os pensamentos gregos e de Kant, expõe sua teoria a partir dos problemas que a linguagem apresenta para o pensamento real. Após a exposição filosófica acerca da metafísica moderna relaciona-se sua influência para a ocorrência da Escola da Jurisprudência dos Interesses, bem como com o problema da discricionariedade judicial, onde o sujeito solipsista decide conforme sua consciência. Sendo que essa corrente de pensamento somente foi derrubada a partir do giro linguístico.

Os marcos filosóficos levam ao impasse da interpretação no Direito: de que maneira a discricionariedade do julgador ultrapassa as barreiras do positivismo, ou melhor, fere a própria democracia. Para abordar tal questão, optou-se pelo método hermenêutico, a fim de contrapor a interpretação e as ideias apresentadas pelos filósofos que construíram o entendimento dentro da metafísica clássica e moderna.

\section{METAFÍSICA CLÁSSICA: A PARTIR DE CRÁTILO DISCUTE-SE A FILOSOFIA DA LINGUAGEM}

Quando se inicia um estudo baseado na filosofia está-se em busca do essencial, ou seja, do que está nas entrelinhas dos problemas e teorias fundamentais das ciências. É aquilo que os olhos não podem ver na primeira observação, tendo em vista que é necessário um esforço para que se consiga visualizar quais são os problemas jurídicos que a sociedade enfrenta, para então buscar possíveis respostas. Por isso, a filosofia do Direito está além do Direito, visto que tende a 
responder as indagações feitas por este. ${ }^{1}$ Dentre essas indagações e problemas que o Direito enfrenta percebe-se que ainda se decide conforme os padrões aristotélicos e da filosofia da consciência, onde a noção de verdade fica adstrita ao dualismo objeto-sujeito. Diz-se problema porque esse dualismo tem elevado a discricionariedade do intérprete da norma.

Esse dualismo vem da busca pela verdade que desde a Antiguidade constituía um problema, algo que deveria ser desvendado. Nesse período o senso comum acreditava que o que era verdade era o mundo sensível, ${ }^{2}$ ou seja, verdadeiro era o que os sentidos poderiam perceber, tocar. Com isso, a verdade passou a ser relacionada à coisa (objeto do mundo sensível), sendo que a linguagem para ser considerada verdadeira deveria registrar adequadamente a coisa. ${ }^{3} \mathrm{Na}$ metafísica clássica a verdade está relacionada ao objeto, a coisa.

Na obra Crátilo, de Platão, é apresentada uma discussão sobre a linguagem, pois são contrapostas duas teses, de um lado o naturalismo, onde cada coisa tem um nome por natureza e de outro o convencionalismo, defendido pelos sofistas, no qual a ligação dos nomes é terminantemente arbitrária e convencional, não há uma relação entre as palavras e as coisas, sendo que Platão tomará uma posição intermediária entre ambas. Isso porque, no naturalismo há a noção de que a significação de uma palavra está ligada ao seu som, enquanto que Platão traça a ideia de que uma afinidade natural deve haver entre o som e a significação da palavra, por isso apesar de as palavras não imitarem os sons, elas representam a essência das coisas. Ou seja, as palavras são a própria coisa, o próprio ser. Logo, para o filósofo, a palavra será justa quando apresentar corretamente a coisa. Essa teoria de Platão representa o pensamento objetivista, no qual as coisas têm características que se relacionam, sendo a tarefa da linguagem ser a expressão correta da ordem objetiva das coisas. ${ }^{4}$

${ }^{1}$ KAUFMANN, Arthur. Filosofia do direito, teoria do direito, dogmática jurídica. In: KAUFMANN, Arthur; HASSEMER, Winfried (Org.). Introdução à filosofia do direito e à teoria do direito contemporâneas. Tradução de Marcos Keel e Manuel Seca de Oliveira. Revisão científica e coordenação de Antonio Manuel Hespanha. Lisboa: Fundação Calouste Gulbenkian, 2002. p. 25.

${ }^{2}$ Conforme explica Danilo Marcondes (Iniciação à história da filosofia: dos pré-socráticos a Wittgenstein. Rio de janeiro: Jorge Zahar, 1997. p. 61) nos textos da obra República de Platão o mundo material ou visível é composto de objetos naturais, particulares, concretos, imperfeitos, mutáveis, perecíveis, enquanto que o mundo inteligível ou das ideias é formado por realidades abstratas, perfeitas, eternas, imutáveis, inteligíveis.

${ }^{3}$ GARCIA-ROZA. Luiz Alfredo. Palavra e verdade: na filosofia antiga e na psicanálise. Rio de Janeiro: Jorge Zahar, 1990. p. 10-11.

${ }^{4}$ OLIVEIRA, Manfredo Araújo de. Reviravolta linguíístico-pragmática na filosofia contemporânea. São Paulo: Edições Loyola, 1996. p. 18-19. 
Por isso, Platão questiona-se sobre qual forma é mais segura para obter o conhecimento, pois através dos nomes é possível conhecer com exatidão a coisa, assim como por meio das coisas em si mesma (visto que uma coisa difere-se a todas as outras que não são seus semelhantes), assim pode-se partir da imagem que reproduz consequentemente a verdade sobre a coisa, ou partir da verdade, para então conhecer a coisa e sua imagem e verificar então se foi acertadamente realizada. Para essa questão Platão responde que se deve começar o conhecimento pela verdade, ou seja, "não é nos nomes que se deve partir, mas que as coisas, muito de preferência a partir dos nomes, devem conhecer-se e investigar-se, partindo delas mesmas". ${ }^{5}$

Essa conclusão de Platão representa a ideia fundamental da metafísica clássica, pois ele quer demonstrar que por meio da linguagem não se chega à verdade sobre as coisas, pois o que é real só é conhecido em si mesmo, sem a intervenção linguística, onde é possível conhecer as coisas sem os nomes. Logo, como a verdade está no objeto, a linguagem seria unicamente um instrumento, sendo que o conhecimento não necessita dela. Nesse sentido, a linguagem não é a formadora da experiência humana, mas sim um instrumento posterior, haja vista, que possui a função de designar com sons o que foi percebido sem ela. Diferencia a linguagem do conhecimento, pois para o filósofo a linguagem possui uma função secundária ao pensamento, o próprio pensar seria uma atividade não linguística. ${ }^{6}$

Portanto, nos seus textos, Platão defende que não há uma autonomia da linguagem em relação às coisas, dessa forma, ele e Aristóteles possuem um entendimento contrário ao convencionalismo, haja vista que, conforme se percebe nas suas teses, não é possível confiar na linguagem, inclusive, os sofistas ${ }^{7}$ gregos haviam formulado muitos paradoxos, como o do cretense mentiroso: “Um cretense diz: todos os cretenses são mentirosos". Ora, quando um cretense diz que todos os cretenses são mentirosos, não se sabe se o que ele diz é mentira ou

\footnotetext{
${ }^{5}$ PLATÃO. Crátilo: diálogo sobre a justeza dos nomes. 2. ed. Lisboa: Sáda Costa, 1994. p. 155-156.

${ }^{6}$ OLIVEIRA, Manfredo Araújo de. Reviravolta linguíístico-pragmática na filosofia contemporânea. São Paulo: Edições Loyola, 1996. p. 22.

7 Segundo Luiz Alfredo Garcia-Roza (Palavra e verdade: na filosofia antiga e na psicanálise. Rio de Janeiro: Jorge Zahar, 1990. p. 56-58) a sofística surge com o fim da monarquia e o início da democracia, quando a lei divina é definitivamente substituída pela lei humana. Os sofistas não defendiam nenhuma doutrina específica nem formavam um grupo com identidade teórica ou político-ideologica. 0 que possuíam em comum era o fato de recusarem qualquer valor que se apresentasse como absoluto. Afora isto, eram hábeis argumentadores e dominavam por completo a técnica da palavra. No lugar de serem mestres da verdade, eram mestres da oratória e da dialética. Através da técnica da palavra possibilitavam àqueles que a empregassem obter êxito nas discussões públicas, por isso não percorriam o caminho da verdade, mas sim o caminho da opinião.
} 
verdade. A partir de Platão tem-se uma noção de metafísica, na medida em que é possível exprimir de suas ideias uma universalidade do discurso que apresenta uma verdade sobre o ser, a coisa. Seu discurso apresenta uma correspondência entre o pensamento e o ser. ${ }^{8}$ Para Josef Simon, ${ }^{9}$ o filósofo grego iniciou a filosofia ontológica, uma vez que “viu no 'ser' das coisas o seu

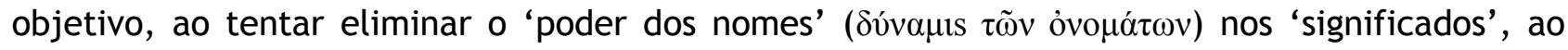
passo que a retórica sofística a ele se manteve referida".

Em Aristóteles surge a primeira Metafísica, após ser discípulo de Platão por dezenove anos elabora sua própria teoria, visto que não satisfeito com a resposta que Platão deu aos sofistas, cria uma teoria voltada para a significação, visando refutar a proposição sofística. Como Aritstóteles não concorda com a ideia de Platão de que as palavras possuíam uma relação mimética com as coisas, rompeu com esse vínculo proposto pelo seu mestre e escreveu a sua teoria baseada na teoria da significação, onde a linguagem será o signo e o ser o significado. Enquanto que em Platão a linguagem é apenas um instrumento, cuja importância é secundária se comparada às coisas e às ideias, e nos sofistas a linguagem apresenta suma importância, tanto que desvincula o ser da verdade. De outro modo, Aristóteles concorda com os sofistas, no sentido do valor que a linguagem possui em sociedade, contudo, na sua teoria será a essência das coisas que darão possibilidade de sentido às palavras. Sem a essência, as palavras perderiam a sua função de significante. ${ }^{10}$

Para o filósofo a metafísica, chamada por ele de a ciência primeira, seria uma ciência que estuda o ser, enquanto ser e os acidentes próprios do ser, ao contrário de outras ciências que o estudam limitadas sob determinado ponto de vista. Assim, a metafísica analisa as indagações sobre “los principios, las causas más elevadas, es evidente que estos principios deben tener una naturaleza propia". ${ }^{11}$

Na sua teoria, Aristóteles traz que o indivíduo é formado por matéria e forma, sendo que a matéria seria como cada um se individualiza e a forma seria de que maneira a matéria se organiza. Desse modo, todos os indivíduos de uma mesma espécie teriam uma mesma forma, diferenciando-se na matéria, tendo me vista que os indivíduos são diferentes uns dos outros, ao menos numericamente. Para ele matéria e forma são impossíveis de serem separadas, visto que

\footnotetext{
${ }^{8}$ Ibid. p. 17-18.

${ }^{9}$ SIMON, Josef. Filosofia da linguagem. Rio de Janeiro: Edições 70, 1990. p. 178.

${ }^{10}$ GARCIA-ROZA, Luiz Alfredo. Palavra e verdade: na filosofia antiga e na psicanálise. Rio de Janeiro: Jorge Zahar, 1990. p. 83-85.

${ }^{11}$ ARISTÓTELES. Metafísica. Madrid: Espasa Calpe, 1999. p. 101.
} 
constituem uma unidade. O ser humano, a partir da abstração e do seu intelecto consegue relacionar os diferentes objetos, a partir dos quais têm a mesma forma, diferenciando-se de acordo com suas qualidades particulares da matéria. Logo, a ideia de ser humano, de homem, é uma natureza comum a todos os homens, a partir da forma de ser humano, por meio dela também é possível distingui-lo dos demais animais. Por isso o que existem são as substâncias dos seres, se não houvesse indivíduos, não existiriam, consequentemente, nem espécies, nem gêneros, ${ }^{12}$ pois, é justamente dessa substância que depende o conhecimento humano.

Explica Aristóteles que o ser pode ser entendido de diversas maneiras, mas estes diferentes sentidos se referem a uma só coisa, ou seja, uma mesma natureza, sendo que não existe entre eles apenas uma similaridade de nome, por exemplo, pela palavra são entende-se tudo aquilo que se refere a saúde, aquilo que a conserva, que a produz, aquilo de que ela é um sinal e quem a recebe; pela palavra medicinal pode-se entender tudo o que se relaciona com a medicina, o que é próprio dela, ou finalmente o que é sua obra; da mesma forma o ser tem muitos significados, mas todas se referem a um princípio único, a sua ideia de substância. Tal coisa se chama ser, porque é uma essência. Nesse sentido, a essência não é o ser, mas sim, ela é ele no ser. Logo, a metafísica seria uma ciência que estuda igualmente os seres enquanto seres. Tendo em vista que cada ciência possui um objeto que lhe é próprio, na metafísica, o seu objeto de análise é o motivo da existência das demais coisas, necessita Aristóteles ao determinar a essência como objeto, estabelecer os princípios e as causas essenciais. Assim, "um hombre, ser hombre y hombre, significan la misma cosa; nada se altera la expression.: el hombre es, por esta duplicación: el hombre es hombre o el hombre es um hombre", isso porque o ser não se separa da unidade, ou melhor, do individual, o mesmo acontece com a essência. ${ }^{13}$

Portanto, tendo em vista que segundo Aristóteles as palavras só possuíam sentido definido porque as coisas possuíam essência, a linguagem não manifestava (teoria defendida Platão) a coisa, mas sim a significava. A palavra, denominada pelo filósofo de símbolo, relaciona-se com a coisa devido a significação e não por semelhança ou imitação. Logo, para que o pensamento e a linguagem ocorram é preciso que as palavras tenham um sentido definido, 0 que é possível a partir da essência. Isso advém da distinção que Aristóteles faz entre o discurso geral e a proposição, onde explica que somente com a proposição pode-se observar quando algo

\footnotetext{
${ }^{12}$ MARCONDES, Danilo. Iniciação à história da filosofia: dos pré-socráticos a Wittgenstein. Rio de janeiro: Jorge Zahar, 1997. p. 72.

${ }^{13}$ ARISTÓTELES. Metafísica. Madrid: Espasa Calpe, 1999. p. 102-103.
} 
é verdadeiro ou falso, sendo que os discursos são verdadeiros quando apresentam as semelhanças com as coisas em si. ${ }^{14}$ Por isso, para o filósofo "dizer que aquilo que é, não é, ou que aquilo que não é, é, é falso. Enquanto que dizer que aquilo que é, é e aquilo que não é, não é, é verdadeiro". ${ }^{15}$ Importante que se distinga semelhança de significação, haja vista que não há uma semelhança completa entre os nomes e as coisas, porque os nomes são limitados, enquanto que as coisas são numericamente infinitas, o que determina que muitas sejam nomeadas com um único nome. A palavra, ou melhor, a linguagem será o símbolo do real, pois como não apresenta uma semelhança completa com a coisa, não poderá ser utilizada no lugar desta, de modo que exprime uma ligação/distância, tendo em vista que, ao mesmo tempo em que a palavra não pode ser entendida como um signo do real, ela expressa uma relação simbólica, cujo sentido é determinado pela intervenção do ser, o que permite, por exemplo, que se diferencie a linguagem humana dos sons realizados pelos animais. ${ }^{16}$

Com o discurso advém o problema de que enquanto este é universal, as coisas são singulares. Assim, através da convenção, as palavras são significativas e para garantir que elas conservem uma significação, ou seja, uma unidade objetiva, Aristóteles utiliza-se da noção da essência das coisas, "o que garante à palavra cão uma significação uma é o mesmo que faz o cão ser cão”. ${ }^{17}$ A comunicação entre os homens somente é possível porque as palavras têm uma unidade de sentido (ao contrário de Platão que defendia a importância secundária da linguagem). A metafísica proposta por Aristóteles também pode ser caracterizada como ontologia, uma vez que a linguagem não traz um discurso do ser, mas somente pode ser compreendida a partir do seu fundamento, ou seja, do ser em si. Dessa forma, a ontologia,

${ }^{14}$ GARCIA-ROZA, Luiz Alfredo. Palavra e verdade: na filosofia antiga e na psicanálise. Rio de Janeiro: Jorge Zahar, 1990. p. 86-87.

15 TOMÁS DE AQUINO, Santo. Verdade e conhecimento. Tradução, estudos introdutórios e notas de Luiz Jean Lauand e Mario Bruno Sproviero. São Paulo: Martins Fontes, 1999. p. 84.

16 OLIVEIRA, Manfredo Araújo de. Reviravolta linguístico-pragmática na filosofia contemporânea. São Paulo: Edições Loyola, 1996. p. 29.

${ }^{17}$ Explica, ainda, Lênio Luiz Streck (Hermenêutica jurídica $\mathbf{e}(\mathrm{m})$ crise: uma exploração hermenêutica da construção do Direito. 10. ed. rev., atual. e ampl. Porto Alegre: Livraria do Advogado, 2011. p. 159) que Aristóteles não elimina a equivocidade que a pluralidade de significações ocasiona, tanto que distingue dois tipos de equivocidade: a primeira decorre de o fato do significado, por ser universal ser dotado de uma multiplicidade inevitável - o universal árvore significa uma pluralidade de árvores individuais, as únicas realmente existentes; a segunda decorre da homonímia. Se a primeira equivocidade é inevitável, a segunda pode ser evitada através da distinção rigorosa dos vários significados de uma palavra. 
dentro na definição de ciência primeira proposta por Aristóteles, seria ainda o estudo das condições de possibilidade da comunicação humana. ${ }^{18}$

Em oposição às teorias de Platão e Aristóteles, os estoicos vão assumir um caráter materialista, pois, para eles apenas o que existe é o corpo, o qual é passível de tensões e acontecimentos, logo, somente o indivíduo singular será real. A noção de essência e universal trazidas por Aristóteles e Platão não apresentariam o real, seriam apenas nomes. Para os estoicos o significado, o significante e o objeto estão ligados. 0 significante seria a palavra, já o significado seria a coisa que é relevada pela palavra, que é formada através do pensamento humano, enquanto que o objeto existe no mundo exterior ao pensamento. Por isso, a palavra e o objeto são corpóreos (ou seja, também são corpos), enquanto que o significado (também chamado de entidade) é incorpóreo, pois presente no pensamento. Embora essa entidade não se confunda com as palavras, somente poderá ser expresso a partir das palavras, logo, ela é o que dá sentido à fala. De modo que, a linha divisória nos estoicos era traçada entre as palavras e o sentido (corpóreos e incorpóreos), tendo em vista que “o fundamental aqui não é a ideia, mas os próprios corpos com suas ações e paixões, não sendo a ideia mais do que um efeito. 0 acontecimento [esse termo é utilizado no sentido estoico como algo que não é um ser, mas um quase-ser, um efeito incorporal dos corpos] pertence à linguagem, mas acontece às coisas; não são seres mas dão-se na superfície dos seres". ${ }^{19}$ A importância dos estoicos é tamanha que posteriormente quando Ferdinand de Saussure realizou a sua interpretação sobre o signo, caracterizando este como a união entre significante e significado, na realidade, utilizou-se da terminologia estoica. ${ }^{20}$

Quando Aristóteles iniciou a tradição do pensamento metafísico, ao longo dos anos, a busca pela verdade continuou na Idade Média, nesse período da metafísica clássica, entretanto, o que comanda é a razão divina, sendo que os autores desse período utilizam-se do pensamento grego, adaptando-o ao cristianismo. Nesse sentido, cientes da teoria da significação de Aristóteles, Lancan e Santo Agostinho vão elaborar suas teorias baseados na função significante da palavra.

${ }^{18}$ OLIVEIRA, Manfredo Araújo de. Reviravolta linguíistico-pragmática na filosofia contemporânea. São Paulo: Edições Loyola, 1996. p. 32.

19 GARCIA-ROZA, Luiz Alfredo. Palavra e verdade: na filosofia antiga e na psicanálise. Rio de Janeiro: Jorge Zahar, 1990. p. 96; 101-102; 105.

20 JAKOBSON, Roman. Linguística e comunicação. Tradução por Izidoro Blikstein e José Paulo Paes. São Paulo: Cultrix, 1977. p. 98. 


\section{政

Em Santo Agostinho a busca pela verdade direciona à interioridade de ser humano, ao invés de coisas ou palavras, por isso, a verdade é ínsita ao indivíduo, pois não é possível adquirila. A compreensão dos signos é possível a partir da interioridade, sendo esta exterior aos signos e aos objetos. Somente com a presença do Absoluto as palavras e coisas possuem sentido, visto que a palavra em si não possui verdade, as palavras somente levam as pessoas a aprender novas palavras (como as palavras são signos, a relação será signo-signo), formando um sistema fechado de significações, por isso elas incitam a busca pela verdade, a qual somente é possível com uma iluminação interior. De modo que, o caminho para a verdade é consequentemente o caminho para Deus, o qual leva à interioridade das pessoas. Essa interioridade é condição de possibilidade para a linguagem, e não o contrário, tendo em vista que o que ocorre, no âmbito exterior, é a relação signo-signo, a qual sem a interioridade não é passível de compreensão. 0 signo é enganador porque não tem uma relação natural com a coisa. Assim, o "Deus agostiniano é ao mesmo tempo íntimo e transcendente, familiar e distante, uma espécie de Unheimlich iluminador do pensamento", ${ }^{21}$ o que demonstra que nessa teoria a verdade está relacionada a algo que não é o sujeito, mas sim Deus, visto que a interioridade do indivíduo depende da iluminação divina.

Para Lancan, tendo em vista a função significante da palavra, a linguagem é uma rede/teia sobre o conjunto de coisas da realidade, cuja utilização permite expressar o mundo simbólico. Para ele as coisas têm um nome devido às relações entre os signos, descartando a ideia de que a denominação advém dos signos ou das coisas, logo, também a verdade somente será possível a partir da interioridade do sujeito. ${ }^{22}$

Para Santo Tomas de Aquino "se o intelecto humano e o divino, permanecendo as coisas, o que é impossível, fossem eliminados, de nenhum modo permaneceria a noção de verdade". ${ }^{23}$ Assim, como a verdade está em Deus observa-se que há a igualdade do intelecto divino e da coisa, tendo em vista que o intelecto divino primordialmente entende a realidade humana, a qual é a sua própria essência, por meio desta o intelecto divino apreende todas as coisas. Dessa forma, a noção de verdade depende da igualdade do intelecto divino com aquela realidade que é sua própria essência, e, por conseguinte do intelecto divino com as coisas

${ }^{21}$ GARCIA-ROZA, Luiz Alfredo. Palavra e verdade: na filosofia antiga e na psicanálise. Rio de Janeiro: Jorge Zahar, 1990. p. 19; 110-113.

22 GARCIA-ROZA, Luiz Alfredo. Palavra e verdade: na filosofia antiga e na psicanálise. Rio de Janeiro: Jorge Zahar, 1990. p. 19; 113-114.

${ }^{23}$ TOMÁS DE AQUINO, Santo. Verdade e conhecimento. Tradução, estudos introdutórios e notas de Luiz Jean Lauand e Mario Bruno Sproviero. São Paulo: Martins Fontes, 1999. p. 125. 
criadas. Ressalta-se que, a adequação entre o intelecto divino e essência divina (realidade, coisas criadas por Deus) não ocorre como entre mesurante e mesurado, tendo em vista que um não é princípio do outro, pelo contrário são totalmente idênticos. ${ }^{24} \mathrm{~A}$ ideia de essência trazida por Santo Tomás de Aquino tem base aristotélica, pois ele adapta o pensamento de Aristóteles ao cristianismo, tanto que utiliza os mesmos termos que são referidos pelo filósofo grego em seus textos.

No medievo apoiado pelas teses aristotélicas a razão divina comandava todas as coisas e é responsável pela noção de verdade. O sujeito estava submetido ao objeto, de modo que a subjetividade somente será construída na Idade Moderna, cujo rompimento paradigmático será o responsável para a construção do Estado Absolutista e demais acontecimentos modernos. De qualquer modo, durante o período medieval o nominalismo será a corrente de pensamento que terá uma postura antimetafísica. ${ }^{25}$

Foi Guilherme de Ockham, filósofo do século XIV, o responsável pela posição nominalista em discussão com a ideia universalista da natureza das espécies. ${ }^{26}$ No nominalismo o universal "corresponde a um conceito por meio do qual nos referimos a essas qualidades ou características", o universal é a alusão a um termo, um conceito, não um ente/ser conforme defendido por Aristóteles, mas ao mesmo tempo não é só uma palavra, tendo em vista que há um relacionamento mental ao conceito, o qual é a referência dos gêneros e espécies. Por isso, defende uma valorização da linguagem frente às coisas e que, consequentemente, não se deve

\footnotetext{
24 Ibid. p. 233.

${ }^{25}$ STRECK, Lênio Luiz. Hermenêutica jurídica $\mathbf{e}(\mathbf{m})$ crise: uma exploração hermenêutica da construção do Direito. 10. ed. rev., atual. e ampl. Porto Alegre: Livraria do Advogado, 2011. p. 165-166.

${ }^{26}$ Para esse tema do universalismo existem nesse período do medievo quatro linhas de pensamento: 0 realismo platônico, o realismo aristotélico, o conceitualismo e o nominalismo que foi explicado acima. 0 realismo platônico defende que os gêneros e espécies (tais como "animal mamífero" e "cavalo") seriam formas ou ideias, portanto, entidades dotadas de uma existência autônoma, pertencentes ao mundo das ideias e independentes tanto das coisas concretas ("este cavalo") quanto de nossos pensamentos ("o conceito de cavalo"). Para o realismo aristotélico, posição adotada por exemplo por São Tomas de Aquino, gêneros e espécies existem nas coisas, como formas da substância individual, e podem ser conhecidos por nós através da abstração, em que destacamos do particular o universal, isto é, percebemos que este indivíduo é um cavalo, um animal mamífero, etc. O conceitualismo foi desenvolvido sobretudo por Pedro Abelardo em sua Lógica para principiantes onde sustenta que os universais são apenas conceitos, ou seja, predicados de sentenças que descrevem o objeto ("Isto é um cavalo"), existindo portanto na mente como meio de unir ou relacionar objetos particulares dotados das mesmas características e qualidades. (MARCONDES, Danilo. Iniciação à história da filosofia: dos présocráticos a Wittgenstein. Rio de janeiro: Jorge Zahar, 1997. p. 132)
} 
supor a existência de entidades metafísicas, como a teoria platônica do mundo inteligível, pois, elas possuem uma explicação deficitária. ${ }^{27}$

O que as coisas de mesmo nome têm comum é apenas a denominação. Conforme se percebe, ao contrário de Guilherme de Ockham, para Aristóteles os conceitos são as diferentes funções da linguagem enquanto demonstração dos diversos aspectos do real, logo, não poderiam ser considerados essências independentes. Ocorre que, o modo como se fala sobre determinadas coisas já demonstra como elas são percebidas, logo, a filosofia deve buscar explicar e demonstrar de maneira crítica de que forma dá-se essa pré-compreensão, cuja mediação é feita através da linguagem. ${ }^{28}$

Pois bem, tendo em mente os marcos filosóficos da metafísica clássica é importante que se destaque em que medida sua influência pode ser observada na postura positivista, bem como, até que ponto a ideia do objeto torna-se um impasse no julgamento pelo Poder Judiciário. Apesar da tentativa no século XIX, de excluir a metafísica da interpretação do Direito, a escola da exegese que surgiu na França em 1804, a jurisprudência dos conceitos criada na Alemanha em 1900 e a doutrina positivista acabaram por incorporar a noção de objeto da metafísica clássica.

Sabe-se que o positivismo refere-se aos fatos, ou seja, a interpretação da realidade será somente o que se pode contar, medir ou pesar ou, algo que se possa definir por meio empírico. No Direito, a manifestação do positivismo dá-se através dos Códigos, da legislação escrita pelo Parlamento. ${ }^{29} \mathrm{Na}$ Escola da Exegese tem-se a noção de juiz boca da lei, ou seja, o mito do dado, não se pode alterar o texto elaborado pelo legislador, porque "fundava-se na concepção da perfeição do sistema normativo, na ideia de que a legislação era completa e de que, na generalidade da lei, encontrava-se solução para todas as situações jurídicas”. Dessa forma, a lei escrita era a única fonte do Direito, onde se devia buscar na vontade do legislador a aplicação das leis. Esta era a função do jurista, buscar o sentido da norma que o legislador quis, e dele apreender para o caso concreto, visto que a interpretação não era permitida. Existindo lacuna ou obscuridade, deveria ser utilizado o método lógico de interpretação. ${ }^{30}$

$\mathrm{Na}$ mesma linha que a Escola da Exegese, na jurisprudência dos conceitos, há uma concepção de sistema jurídico fechado, auto subsistente. Como na Alemanha não havia os

${ }^{27}$ Ibid. p. 131-132.

28 OLIVEIRA, Manfredo Araújo de. Reviravolta linguiístico-pragmática na filosofia contemporânea. São Paulo: Edições Loyola, 1996. p. 33.

${ }^{29}$ STRECK, Lenio Luiz. Verdade e Consenso. São Paulo: Saraiva, 2011. p. 31.

30 HERKENHOFF, João Baptista. Como aplicar o Direito (à luz de uma perspectiva axiológica, fenomenológica e sociológico-política). Rio de Janeiro: Forense, 1994. p. 35. 
Códigos da mesma forma que na França, basearam-se nos sistemas de normas do Direito Romano, de modo que o Direito era visto como "um corpo de normas positivas. Conferia primado a norma legal e as respectivas técnicas de interpretação. Negava qualquer fundamento absoluto ou abstrato a idéia do Direito". ${ }^{31}$

Esse positivismo presente nas duas escolas acima mencionadas é considerado positivismo exegético, posteriormente Hans Kelsen partindo da doutrina positivista que já era aplicada e procurando resolver o problema da interpretação formula o positivismo normativo, enfatizando a semântica ao invés da sintaxe. Em sua teoria pura do Direito Kelsen supera a questão da interpretação pelo julgador. Ele faz uma divisão entre Direito e ciência do Direito, diferenciando, por conseguinte, interpretação como ato de vontade e interpretação como ato de conhecimento. 0 primeiro caso está presente quando se aplicam as normas, pois nesse momento cria normas, que são aplicadas ao caso em concreto, tal é a interpretação dos órgãos jurídicos. Enquanto que o segundo produz proposições, pois, interpreta de modo abstrato a norma que é dada, sendo esta a interpretação utilizada pelo cientista do Direito. Nesse espaço de movimentação trazido pela interpretação como ato de vontade, está presente o solipsismo do julgador. ${ }^{32}$

De qualquer modo a crença dos julgadores de que o positivismo exegético continua sendo a forma correta para decidir, a edição de súmulas vinculantes e conceitos prontos pela jurisprudência, além da contínua busca pela verdade real, como se houvesse essências, ${ }^{33}$ ratifica essa perspectiva objetivista, onde não se pode questionar o produto, ou seja, as normas e ementas, porque o que domina é a razão do legislador, ou do órgão superior, dependendo da discricionariedade em questão. Portanto, as ideias platônicas podem ser bem relacionadas com a formulação de conceitos jurídicos abstratos prévios, presentes no entendimento dos Tribunais. Em linhas gerais, o sentido está na própria coisa, na sua essência, imutável e permanente.

\footnotetext{
${ }^{31}$ Ibid. p. 37-38.

32 STRECK, Lênio Luiz. Verdade e Consenso. São Paulo: Saraiva, 2011. p. 34.

33 Id. O que é isto - decido conforme minha consciência? Porto Alegre: Livraria do Advogado, 2010. p. 59.
} 


\section{METAFÍSICA MODERNA: DO SUBJETIVISMO À DISCRICIONARIEDADE}

A metafísica moderna é inaugurada com a noção de sujeito trazida por Descartes. Tratase de uma ruptura filosófica, através da qual é possível entender a modernidade e o papel do Direito. Isso porque, a modernidade cria o sujeito, o qual, na realidade cria a modernidade. É com a modernidade que se altera o espaço da experiência e a forma como o tempo histórico até então era demarcado, pois no medievo, com o predomínio do pensamento cristão, e o assujeitamento do sujeito à razão divina, a realidade da sociedade ficava adstrita a uma dupla tensão no presente “de uma lado, o passado que condiciona a vida a partir de seu caráter pedagógico; de outro, o futuro que se mantém obscuro pelo temor/ certeza da chegada do juízo final". ${ }^{34}$ De suma importância essa ruptura para a ocorrência do pensamento hermenêutico nos moldes como é hoje.

Diante de uma realidade que foi colocada em dúvida, em Descartes percebe-se que é apenas o sujeito (que diz: eu penso) que vai continuar isento de críticas. O filósofo parte do ponto de que como todos os pensamentos que as pessoas têm quando estão acordadas, também podem thes ocorrer enquanto dormem, sem que nesse caso sejam considerados verdadeiros, resolveu simular que todas as coisas que até então haviam passado pelo seu espírito não eram mais verdadeiras que as ilusões de seus sonhos. Porém, ao considerar que tudo era falso, chega à conclusão de que ele, o ser pensante, precisava ser alguma coisa. Logo, adota como primeiro princípio de sua teoria filosófica a máxima do penso, logo existo, visto que considerou uma verdade bastante abalizada e correta, podendo ser livre de todas as críticas dos céticos diante de sua teoria. Descartes foi bem feliz na sua formulação subjetivista, uma vez que ao notar que em penso, logo existo, não há nada que comprove que ele diz a verdade, tão somente que para pensar é preciso existir, vai estabelecer como regra geral que apenas as coisas que se idealiza de maneira clara e distinta é que são verdadeiras, a dificuldade que resta é distinguir de maneira correta quais são as coisas que se concebe distintamente. ${ }^{35}$

O filósofo vai além desse problema dos sonhos, entende que os sentidos também podem enganar as pessoas, como quando alguém está com icterícia e enxerga tudo amarelo, ou então

\footnotetext{
${ }^{34}$ STRECK, Lênio Luiz. Hermenêutica jurídica e(m) crise: uma exploração hermenêutica da construção do Direito. 10. ed. rev., atual. e ampl. Porto Alegre: Livraria do Advogado, 2011. p. 171-172.

35 DESCARTES, René. Discurso de método. Tradução de Maria Ermantina Galvão. São Paulo: Martins Fontes, 1996. p. 38-39.
} 
ao observar os corpos celestes, estes parecem muitos menores do que realmente o são. Tendo em vista o período de forte influência cristã em que Descartes escreveu sua filosofia, vai estabelecer que Deus é o ser perfeito, aquele que fornece o conhecimento e permite que os indivíduos vejam as coisas claramente e distingam àquelas eivadas de verdade. Conclui que independente de estar dormindo ou acordado, o sujeito não se deve deixar persuadir a não ser pela evidência da razão que possui em si mesmo, pois é somente ela que vai estabelecer o que é verdadeiro, ou seja, vai permitir que se observe se as coisas e as palavras possuem um fundamento de verdade. Esta será encontrada nos pensamentos que cada indivíduo elabora quando está acordado. ${ }^{36}$ Desse modo, no livro do Discurso do Método, Descartes estabelece que o método deveria ser o momento da subjetividade e da probabilidade de certeza.

A consequência do argumento do cogito (penso, logo existo) foi o solipsismo cartesiano, onde há isolamento do eu em relação a todo o mundo externo, bem como ao próprio corpo, que também se considera externo ao eu. Esse solipsismo apresenta uma certeza tão forte porque é carregada de subjetivismo. Contudo, como Descartes pretende construir um conhecimento científico, tanto que chama o seu livro de Discurso do Método, procura encontrar uma perspectiva para ultrapassar essa ideia de que a única realidade certa é a existência do puro pensamento. Tal intento foi possível a partir da afirmação da existência de Deus, o que rompeu com o solipsismo e trouxe a noção de algo fora do cogito. Essa existência decorre da ideia inata que os indivíduos possuem de Deus, o qual é perfeito e permite com se veja/pense com clareza, observa-se então um realismo, "no qual, a existência e a inteligibilidade do mundo externo são garantidas pela existência de Deus, sendo o conhecimento a representação verdadeira, a correspondência entre a ideia e o objeto externo". ${ }^{37}$

Por isso, Descartes constrói uma reflexão que não depende da tradição e da linguagem, tendo em vista que é a consciência, a subjetividade, que permite a certeza plena, a qual é o problema do conhecimento, sem a necessidade de uma mediação linguística, uma vez que é através da autointuição que se cria o conhecimento, sem a interferência da comunidade linguística. ${ }^{38}$ À diferença dos filósofos medievais da metafísica clássica que propunham a verdade como razão divina, Descartes, apesar de trazer a ideia da existência de Deus como método para

${ }^{36}$ DESCARTES, René. Discurso de método. Tradução de Maria Ermantina Galvão. São Paulo: Martins Fontes, 1996. p. 45-46.

${ }^{37}$ MARCONDES, Danilo. Iniciação à história da filosofia: dos pré-socráticos a Wittgenstein. Rio de janeiro: Jorge Zahar, 1997. p. 169; 171-172.

38 OLIVEIRA, Manfredo Araújo de. Reviravolta linguiístico-pragmática na filosofia contemporânea. São Paulo: Edições Loyola, 1996. p. 33. 
romper com o solipsismo de sua própria teoria, a verdade estará na razão do indivíduo, o qual enxerga ao mundo com clareza e é passível de tomar suas decisões conforme sua própria consciência.

Outro pensador importante desse período foi Thomas Hobbes que desenvolveu uma forte teoria sobre o envolvimento entre o indivíduo e o Estado na idade moderna. Em Hobbes o estado de natureza, no qual o homem se encontrava, colocava-o em constante guerra de todos contra todos, o que o levou à vida em sociedade organizada, como meio de sobrevivência. Esse estado de natureza descreve como o homem se comportaria quando não está submetido a leis e contratos impostos pela sociedade. Por isso, os homens são essencialmente iguais, tendo em vista que as diferenças entre eles são irrelevantes, sendo que o poder soberano é concebido para permitir que os indivíduos coexistam, impedindo o estado de natureza, onde acabariam por se exterminar uns aos outros. A construção e o funcionamento da sociedade pressupõe que o individuo ceda parte de seus direitos ao poder soberano, cujo poder deve ser exercido de forma absoluta para que a sociedade seja eficaz, o que não demanda uma realização pessoal do soberano, mas sim que o soberano exerça o seu poder em nome dos indivíduos que a ele o confiaram. Tudo isso ocorre porque o homem deseja sobreviver e é em nome dessa sobrevivência que firma o contrato com os demais indivíduos da sociedade. Em razão dessa teoria do contrato, Hobbes é considerado um contratualista, tendo em vista que entende que a sociedade civil resulta de um contrato firmado entre os indivíduos, sendo que o poder absoluto é o que garante a paz civil. ${ }^{39}$

$\mathrm{Na}$ sua tese contratualista ${ }^{40}$ a linguagem é um instrumento fundamental para a formulação do Estado, pois é através dela que as pessoas podem compreender e aderir ao pacto

\footnotetext{
${ }^{39}$ MARCONDES, Danilo. Iniciação à história da filosofia: dos pré-socráticos a Wittgenstein. Rio de janeiro: Jorge Zahar, 1997. p. 197-198.

40 Importante observar que além de Hobbes outros dois filósofos também são responsáveis em defender as teses contratualistas acerca do Estado, são eles John Locke e Jean-Jacques Rousseau. Para Locke a sociedade resulta de uma união de indivíduos, visando garantir suas vidas, sua liberdade e sua propriedade, ou seja, aquilo que pertence a cada um. É em nome dos direitos naturais do homem que o contrato social entre os indivíduos que cria a sociedade é realizado, e o governo deve portanto comprometer-se com a preservação desses direitos. A legitimidade do poder reside em sua origem o consentimentos dos indivíduos que o constituíram, e que podem portanto retirá-lo daqueles que não governam no interesse da maioria ou que ameaçam a liberdade e os direitos dos indivíduos. Para Rousseau o contrato social é o modo para que se preserve a liberdade natural do homem e a o mesmo tempo garantir a segurança e o bem-estar que a vida em sociedade pode lhe dar. Segundo a sua teoria do contrato social, a soberania política pertence ao conjunto dos membros da sociedade. 0 fundamento dessa soberania é a vontade geral, que não resulta apenas na soma da vontade de cada um. A vontade particular e individual de cada um diz respeito a seus interesses específicos, porém
} 
social. Se não há uma correta compreensão do pacto, consequentemente, ocorre uma má formação do Estado. A linguagem terá a função de construir as relações sociais e políticas, sendo que a sua interpretação equivocada e subjetiva é o que ocasiona os maiores riscos para o Estado. Seu entendimento filosófico permite sustentar a origem e a formação do Estado, além de romper com as teorias metafísicas medievais. Hobbes também pode ser considerado um nominalista, devido a essa importância que acarreta à linguagem. De qualquer modo fica evidente que foi a vontade dos homens que faz com que eles consigam vencer a barbárie. ${ }^{41}$ A palavra vontade é de suma influência quando se discute acerca do solipsismo e discricionariedade, conforme se verá a seguir.

Por meio da filosofia crítica de Immanuel Kant, a metafísica moderna ganha uma nova visão para o conhecimento, pois "abalou as estruturas do direito natural ao questionar o dogmatismo metafísico e ao defender a autonomia ética e normativa". Construiu a teoria na qual a linguagem possui um caráter acessório, cuja função é auxiliar na medida em que idealiza as palavras como signos das representações, ou seja, são formas sensíveis que ligam conteúdos inteligíveis, sendo estes últimos àqueles que representam genuinamente as coisas. Assim, “o signo limita-se a acompanhar o conceito como guardião, para produzir-lhe oportunamente, o que relega a linguagem a uma função auxiliar, uma vez que a função principal é reservada ao pensamento". ${ }^{42}$ Dessa forma, segundo Kant a verdade formal seria a concordância do conhecimento com o objeto em análise, ou então do conhecimento consigo mesmo, por isso, "a verdade é conhecida como uma relação imanente ao espírito, a concordância do conhecimento com o objeto representado. A verdade seria a objetividade do pensamento". Essa objetividade a que se refere o filósofo pode ser reduzida ao critério de validade universal do juízo, sendo compreendida como aquilo que se impõe à razão comum da todos os homens. Dessa forma, "a verdade é o acordo do juízo com as leis imanentes da razão; unidade entre o subjetivo e o objeto". ${ }^{43}$

enquanto cada cidadão e membro da comunidade, o indivíduo deve possuir também uma vontade que se caracteriza pela defesa do interesse coletivo, do bem comum. (MARCONDES, Danilo. Iniciação à história da filosofia: dos pré-socráticos a Wittgenstein. Rio de janeiro: Jorge Zahar, 1997. p. 199-201)

${ }^{41}$ STRECK, Lênio Luiz. Hermenêutica jurídica $\mathbf{e}(\mathrm{m})$ crise: uma exploração hermenêutica da construção do Direito. 10. ed. rev., atual. e ampl. Porto Alegre: Livraria do Advogado, 2011. p. 169-170.

42 Ibid. p. 177.

${ }^{43}$ LAUAND, Luiz Jean; SPROVIERO, Mario Bruno. In: TOMÁS DE AQUINO, Santo. Verdade e conhecimento. Tradução, estudos introdutórios e notas de Luiz Jean Lauand e Mario Bruno Sproviero. São Paulo: Martins Fontes, 1999. Tomas de Aquino. p. 87. 


\section{ISSN 1981-3694

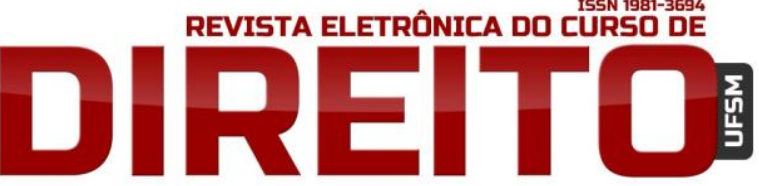

O PARADIGMA DA VERDADE QUE PERPASSA AS METAFÍSICAS CLÁSSICA E MODERNA E DETERMINA AS DECISÕES JUDICIAIS

Em Kant as experiências humanas necessitam ser avaliadas segundo o eu penso, uma vez que ao se conectar em uma consciência, o individuo pode, diante das diferentes representações apontar para uma unidade de consciência. Diferentemente do eu cartesiano, o eu penso kantiano não é puro e posterior às experiências, muito antes, pelo contrário, são as experiências que the dão unidade, de modo que não pode afastar-se delas. Desse modo, como na dialética transcendental a razão "não produz conhecimento porque não remete a objetos de uma experiência possível", para o filósofo a metafísica como era concebida não poderia ser considerada uma ciência porque não tem objetos e não produz um conhecimento do real. Isso porque, as questões sobre o cosmo, a perfeição de Deus e a imortalidade da alma não se manifestam no tempo e no espaço, são transcendentes, cujos conceitos não têm relação com a intuição. Logo, suas discussões baseiam-se no campo do agir ético, onde concebeu o homem não como um sujeito do conhecimento, mas sim agente livre e racional. ${ }^{44}$ Conforme se observa na sua crítica transcendental ainda está presente a noção do sujeito enquanto assujeitador das coisas/objetos.

Streck traz o entendimento de que a análise da linguagem em Kant é problemática porque este não admite que a discussão se reduza a linguagem, por isso a coloca como um instrumento secundário. De modo que para Kant a palavra (ou signo) não apresenta uma relação natural com o significado, até porque este não faz parte da palavra, visto que é alheio a ela, já que pertence ao conhecimento a priori. Somente a partir de um conceito o significante, que não possui sentido, completa seu ciclo de significação, ou seja, é o conceito que faz o signo significativo. $^{45}$

Foi Nietzsche, o responsável pelo rompimento do paradigma metafísica-essencialista proveniente dos filósofos gregos, tendo em vista que para ele não existe "nenhuma semelhança, nenhuma afinidade prévia entre conhecimento e essas coisas que seria necessário conhecer", isso porque para rebater Kant defende que as condições da experiência e aquelas que o objeto possui são diferentes. Defende a ruptura entre o conhecimento e as coisas, por isso que o último princípio epocal da modernidade, formulado pelo filósofo é chamado de a vontade do poder, ou seja, comando. Porém "trata-se de uma forma rebuscada de positivismo uma vez que o direito

\footnotetext{
${ }^{44}$ MARCONDES, Danilo. Iniciação à história da filosofia: dos pré-socráticos a Wittgenstein. Rio de janeiro: Jorge Zahar, 1997. p. 212.

45 STRECK, Lênio Luiz. Hermenêutica jurídica e(m) crise: uma exploração hermenêutica da construção do Direito. 10. ed. rev., atual. e ampl. Porto Alegre: Livraria do Advogado, 2011. p. 178.
} 
passa a depender de discursos adjudicadores e protagonismo do poder do intérprete", ${ }^{46}$ haja vista que nessa perspectiva a ideia antecede a matéria.

No campo da linguagem Nietzsche entende que ela se interpõe entre o pensamento e o real, pois dá forma ao modo que as pessoas pensam aquilo que é pensado. Observa que a linguagem possui concepções e conceitos históricos que podem levar ao erro, ao engano, contudo acredita não existir uma solução para tal problema, uma vez que uma nova linguagem estaria sujeita as mesmas dificuldades. Em sua crítica afirma que "a crença da gramática, no sujeito e no objeto linguístico, e nas palavras de atividade, subjugou até agora os metafísicos: esta crença eu ensino a abjurar”, sendo que como a linguagem é exterior ao pensamento formaria um empecilho, já que na realidade não se pensa em palavras, porque "quem pensa em palavras [...] não pensa as coisas, os objetos, não pensa objetivamente", de modo que pensar seria um luta contra a linguagem, pois "estamos habituados, onde as palavras nos faltam, a não pensar com rigor, porque é penoso continuar a pensar com rigor: e outras vezes conclui-se automaticamente que onde termina o reino das palavras aí termina o reino da existência". ${ }^{47}$

Conforme se observa a busca pelo conhecimento, pela verdade, na metafísica moderna traz a ideia da segurança, uso seguro. A virada do subjetivismo estabelece que a maneira correta do uso da razão é a capacidade de julgar, isso faz com que a vontade (vontade do poder trazida por Nietzsche) supere a razão. Tal perspectiva moderna possui clara influencia para a corrente da jurisprudência dos interesses, na qual o juiz é o sujeito que vai buscar a vontade do legislador quis dizer com a lei, oportunizando uma discricionariedade ao julgador.

A Jurisprudência dos Interesses é uma escola hermenêutica que surgiu na Alemanha, no início do século XX. Teve como representantes Philipp Heck, Max Rümelin, Paulo Oertman e Stampe. Partilhava que deveriam ser investigados os interesses, onde as normas jurídicas são juízos de valor a respeito desses interesses, de modo que o juiz diante do caso concreto deve encontrar o interesse que o legislador procurou proteger. A sentença, ou melhor, a solução do litígio deve abarcar os interesses que estão em disputa, cabendo ao juiz sopesar esses interesses em conflito. 0 objeto dessa análise dos interesses é uma solução justa ao caso concreto. Essa escola parte de duas ideias basilares: a primeira é de que o juiz deve obedecer o Direito positivo, sendo sua função “ proceder ao ajuste de interesses, em resolver conflitos de interesses, do mesmo modo que o legislador [...] a valoração dos interesses levada a cabo pelo

\footnotetext{
${ }^{46}$ Ibid. p. 180-181.

47 BRAIDA, Celso R. Filosofia e linguagem. Florianópolis: Rocca Brayde, 2011. p. 62-65.
} 
legislador deve prevalecer sobre a valoração que o juiz pudesse fazer segundo seu critério pessoal"; a segunda consiste na "função do juiz não se deve limitar a subsumir os fatos as normas", pois, "compete-lhe também construir novas regras para as situações que a lei não regulou e, ainda, corrigir as normas deficientes". Por isso, o julgador deveria proteger a totalidade dos interesses do legislador, sendo que a partir da sua subjetividade irá analisar como isso irá ocorrer, logo, nos conflitos de interesse o juiz irá se basear nas suas próprias avaliações, atinente ao pensamento social vigente, para então combinar os interesses do legislador. ${ }^{48}$ Aparece então a figura do intérprete. 0 juiz nesse caso tem o poder para isso, manusear 0 procedimento para então manifestar o justo.

Explica Karl Larenz que a jurisprudência dos interesses aos poucos substituiu os rígidos conceitos elaborados pelo Parlamento, através da ideia da ponderação diante de uma situação complexa, bem como da visualização dos conflitos de interesses, sendo seus critérios utilizados para a ocorrência da conformidade na resolução desses conflitos, de modo a preservar a ordem jurídica vigente quando do julgamento do caso em concreto. Para isso "deu aos juízes uma consciência sã, tornando frequentemente supérfluas as pseudo-motivações.”, permitindo que a jurisprudência contemplasse os "eventos da vida, tornando-se metodicamente mais consciente, mais livre e mais diferenciada". Logo, supriu as necessidades da época em que foi criada, uma vez que procurava ultrapassar os limites da jurisprudência dos conceitos. ${ }^{49}$ Conforme se observa Karl Larenz sustenta que a jurisprudência tornou-se mais consciente, o que se pode relacionar claramente com a filosofia da consciência, visto que esta advém da vontade do julgador.

Além disso, a metafísica moderna está ligada ao problema da discricionariedade judicial, o qual acaba por aplicar de forma errônea o próprio positivismo normativo. É esse sujeito solipsista (Selbstsüchtiger - egoísta, que se basta em si mesmo) que se encarrega de realizar sua própria inquisição do processo, pois ele vai produzir a prova ex officio e vai decidir de acordo com os princípios do livre convencimento do juiz e da livre apreciação da prova. Porém, isso cria o problema da discricionariedade frente a um Estado Democrático de Direito, o qual, após toda a luta para garantia dos direitos individuais e fundamentais, delega ao juiz a livre possibilidade de decidir de maneira arbitrária. O sujeito solipsista é aquele que decide conforme sua consciência, tendo em vista que o mundo é apenas um esboço daquilo que ele quer

48 HERKENHOFF, João Baptista. Como aplicar o Direito (à luz de uma perspectiva axiológica, fenomenológica e sociológico-política). Rio de Janeiro: Forense, 1994. p. 63-65.

${ }^{49}$ LARENZ, Karl. Metodologia da Ciência do Direito. 3. ed. Lisboa: Fundação Calouste Gulbenkian, 1997. p. 77. 
e decide que é. Dessa forma de pensar decorrem muitos jargões como sentença vem de sentire, ou seja, a decisão estaria ligada às sensações do juiz. ${ }^{50}$

Após a Constituição de 1988, arreigou-se um entendimento de que "sob o pretexto de 'derrubarmos' o juiz boca-da-lei (que, na Justiça do Trabalho, nunca foi assim), coloca-se no seu lugar o império dos princípios”. Ocorre que, para a adoção desses princípios não há limites, e com a errônea interpretação da teoria da argumentação de Alexy, a importação da jurisprudência dos valores e a própria ilusão brasileira ao ativismo judicial do commom law instaurou-se a possibilidade de ponderação de princípios. O que faz com que mesmo com a separação dos poderes, o Judiciário faça às vezes de Parlamento. Porém após séculos para a construção do Direito, não se pode permitir que o Judiciário decida de qualquer modo e crie entendimentos, ${ }^{51}$ cuja possibilidade de mudança somente é possível a muito custo pelo entendimento de poucos juízes e filósofos do Direito.

Apesar da influência do dualismo objeto-sujeito que permanece nas decisões judiciais, a ruptura com tal pensamento, ocorre no século XX, a partir do giro-linguístico, para o qual se comungaram as ideias de Heidegger e Wittgeinstein, além de Austin, Gadamer, Habermas, dentre outros. A mudança está na transferência do conhecimento para o campo da linguagem, ou seja, compreender que a linguagem através da ação dá sentido ao mundo, pois “existe a descoberta de que, para além do elemento lógico-analítico, pressupõe-se sempre uma dimensão prático-pragmático". ${ }^{52}$ Tendo em vista que a análise pormenorizada do referido giro não faz parte do presente estudo, importa referir que é a partir dele que o pensamento hermenêutico consegue superar o dualismo e ao menos no âmbito filosófico, aplicar o Direito em conformidade com a democracia.

Assim, diante dessa reviravolta hermenêutica Streck questiona-se se está superado o esquema sujeito-objeto. Para ele, ocorreram certos avanços para a concretização de direitos, contudo, ao mesmo tempo a noção de sujeito-objeto continua a crescer a partir da formulação de conceitos prévios, por meio de súmulas, jurisprudências dominantes, sob a desculpa de que a lei “não pode abarcar todas as hipóteses de aplicação. O paradoxal é que a institucionalização

50 STRECK, Lênio Luiz. O que é isto - decido conforme minha consciência? Porto Alegre: Livraria do Advogado, 2010. p. 60-61.

51 STRECK, Lenio Luiz. Quanto vale o narcisismo judicial? Um centavo? CONJUR, mai. 2012. Seção Senso Incomum. Disponível em: <http://www.conjur.com.br/2012-mai-17/senso-incomum-quanto-valenarcisismo-judicial-centavo> Acesso em: 24 abr. 2014.

${ }^{52}$ Id. O que é isto - decido conforme minha consciência? Porto Alegre: Livraria do Advogado, 2010. p. 14. 
da súmula com efeito vinculante aponta na direção contrária, isto é, parece que os juristas 'descobriram' um modo de 'abarcar as múltiplas hipóteses de aplicação de uma lei'”. Ainda, quando da análise do caso concreto, diante da jurisprudência dos interesses, a comunidade jurídica, espera que o intérprete/julgador, procure os valores que são escondidos no texto legal. Ocorre que, com o giro linguístico, evidente que a norma não pode ficar a mercê da vontade do intérprete, através dos ensinamentos de Gadamer observa-se que por meio da "antecipação de sentido que se dá na applicatio - porque não há cisão entre interpretar e aplicar - funciona como uma blindagem contra a discricionariedade na atribuição dos sentidos". ${ }^{53}$

Essa posição positivista e a forma como o pensamento está “evoluindo" no Poder Judiciário, onde não se consegue desligar do esquema sujeito-objeto, bem como dos paradigmas presentes na metafísica clássica e moderna, sendo que as decisões, inclusive dos órgãos superiores, apresentam um misto de objetivismo e subjetivismo. A preocupação com a limitação do poder, cuja discussão já estava presente nas teorias contratualistas do Estado, em um Estado Democrático de Direito não pode permitir que as arbitrariedades realizadas pelo Poder Judiciário continuem a ocorrer, muito menos que se propaguem ideias de que sentenças vêm de sentire. Por isso, parece que se retrocede na história filosófica, quando ao invés de se interpretar a norma por meio da hermenêntica, o intérprete permanece arreigado a filosófica da consciência e aos paradigmas aristotélicos.

\section{CONCLUSÃO}

Conforme restou evidenciado a filosofia possui um papel muito importante para a aplicação do Direito e na forma com que o processo de decisão é tomado. A revolução ocorrida com a filosofia da linguagem mudou a forma como era observado o mundo, sendo que o Direito também se transformou de acordo com o pensamento filosófico. A crise que culminou no protagonismo do poder judiciário e na discricionariedade do intérprete possui relação com a crise que o conhecimento passou durante a metafísica clássica e moderna, tendo em vista que a busca pela verdade e pela origem do conhecimento acabou por construir duas correntes dominantes.

${ }^{53}$ Id. Verdade e Consenso. São Paulo: Saraiva, 2011. p. 422-423. 
A primeira provém da metafísica clássica, onde se acreditava que o sentido estava nas coisas. Conforme defendia Aristóteles, as coisas possuíam uma essência e era ela que proporcionava o sentido. Na Antiguidade as teorias que analisaram a linguagem esforçaram-se para combater o pensamento dos sofistas, tendo em vista que a própria linguagem criava armadilhas, por isso a verdade, o conhecimento estava no exterior, na coisa. Nos paradigmas construídos por Aristóteles, a linguagem significava a coisa, sendo que a palavra relacionava-se com a coisa devido a significação, construindo a sua teoria da significação. Durante o medievo também é possível observar que o conhecimento não pertencia ao indivíduo, tendo em vista que ele só era possível com a razão divina. O que comandava o campo da filosofia era a razão divina, tanto que Santo Agostinho entendeu que as palavras (signos) somente levavam as pessoas a aprenderem novas palavras, formando um sistema fechado de significações, a verdade apenas era possível com a iluminação divina.

No campo da metafísica moderna, rompeu-se coma ideia do objeto. A partir do argumento do cogito eu penso, logo existo de Descartes passa-se a adotar a filosofia da consciência, nesse contexto, é o sujeito o senhor do mundo, do seu destino, é e ele quem comanda e sub-roga o objeto. Kant com a sua construção do eu transcendental cria a ideia do conhecimento a priori, sendo que para o filósofo era possível solucionar o problema do conhecimento a partir da de conceitos de entendimento e da razão. Sendo a razão que o sujeito possui aquela que prevalece, valendo-se a linguagem como um instrumento. Em discordância ao pensamento de Kant, Nietzsche formula o último conceito epocal da modernidade que é a vontade do poder, ou seja, o interprete vale-se do seu solipsismo e discricionariedade no momento de decidir.

Toda essa concepção de que a verdade está no objeto ratifica a ideia de que a verdade depende de conceitos prontos, entendimentos dominantes e extratos que condicionem toda a jurisprudência, além de criar mecanismos no próprio sistema processualista visando barrar recursos cujo entendimento divirja daquele dominante. Isso cria no ideário jurista que não se pode questionar o produto do legislador e dos órgãos superiores. Desse modo, as ideias platônicas e paradigmas aristotélicos podem ser bem relacionadas com a formulação de conceitos jurídicos abstratos prévios, presentes no entendimento dos Tribunais e com a busca pela essência da norma.

Da mesma forma a concepção de que a verdade está no sujeito, intimamente relacionase com a Escola da Jurisprudência dos Interesses, onde se ressalta a vontade do intérprete como 
aquela que prepondera diante da norma, tendo em vista que é justamente esse o dever do julgador, dar à norma a correta interpretação diante do caso concreto e contexto histórico vigente no momento do processo. Além disso, a metafísica moderna trouxe consigo o problema do solipsismo, o protagonismo do intérprete, onde o julgador sob o pseudo argumento de que está protegendo os direitos fundamentais baseia-se em princípios, realizando uma ponderação equivocada ao sistema jurídico brasileiro. Assim, os julgadores continuam a basear suas decisões de acordo com a sua consciência, desconsiderando as normas processuais dispostas no Código de Processo Civil, a fim de que o processo possua andamento de acordo com a sua vontade.

Diante da influência do dualismo objeto-sujeito que permanece nas decisões judiciais, sua ruptura no campo da filosofia somente foi possível com o giro linguístico ocorrido no século $X X$. Evidente que a partir dele o pensamento hermenêutico conseguiu superar o dualismo e ao menos no âmbito filosófico, aplicar o Direito em conformidade com a democracia. Porém é certo que, as discussões acerca da filosofia da linguagem continuam a ocorrer e o caminho filosófico é infinito, tendo em vista que permite que se busquem soluções aos problemas que por vezes não se desvelam facilmente. Assim, cabe a filosofia da linguagem o árduo estudo em defesa da democracia e de um positivismo que não viole os direitos fundamentais dos cidadãos e ao mesmo tempo proteja a democracia.

\section{REFERÊNCIAS}

ARISTÓTELES. Metafísica. Madrid: Espasa Calpe, 1999.

BRAIDA, Celso R. Filosofia e linguagem. Florianópolis: Rocca Brayde, 2011.

DESCARTES, René. Discurso de método. Tradução de Maria Ermantina Galvão. São Paulo: Martins Fontes, 1996.

GARCIA-ROZA. Luiz Alfredo. Palavra e verdade: na filosofia antiga e na psicanálise. Rio de Janeiro: Jorge Zahar, 1990.

HERKENHOFF, João Baptista. Como aplicar o Direito (à luz de uma perspectiva axiológica, fenomenológica e sociológico-política). Rio de Janeiro: Forense, 1994.

JAKOBSON, Roman. Linguística e comunicação. Tradução por Izidoro Blikstein e José Paulo Paes. São Paulo: Cultrix, 1977. 
KAUFMANN, Arthur; HASSEMER, Winfried (Org.). Introdução à filosofia do direito e à teoria do direito contemporâneas. Tradução de Marcos Keel e Manuel Seca de Oliveira. Revisão científica e coordenação de Antonio Manuel Hespanha. Lisboa: Fundação Calouste Gulbenkian, 2002.

LARENZ, Karl. Metodologia da Ciência do Direito. 3. ed. Lisboa: Fundação Calouste Gulbenkian, 1997.

LAUAND, Luiz Jean; SPROVIERO, Mario Bruno. In: TOMÁS DE AQUINO, Santo. Verdade e conhecimento. Tradução, estudos introdutórios e notas de Luiz Jean Lauand e Mario Bruno Sproviero. São Paulo: Martins Fontes, 1999.

MARCONDES, Danilo. Iniciação à história da filosofia: dos pré-socráticos a Wittgenstein. Rio de Janeiro: Jorge Zahar, 1997.

OLIVEIRA, Manfredo Araújo de. Reviravolta linguíistico-pragmática na filosofia contemporânea. São Paulo: Loyola, 1996.

PLATÃO. Crátilo: diálogo sobre a justeza dos nomes. 2. ed. Lisboa: Sáda Costa Editora, 1994.

SIMON, Josef. Filosofia da linguagem. Rio de Janeiro: Edições 70, 1990.

TOMÁS DE AQUINO, Santo. Verdade e conhecimento. Tradução, estudos introdutórios e notas de Luiz Jean Lauand e Mario Bruno Sproviero. São Paulo: Martins Fontes, 1999.

STRECK, Lenio Luiz. Hermenêutica jurídica $\mathbf{e}(\mathrm{m})$ crise: uma exploração hermenêutica da construção do Direito. 10. ed. rev., atual. e ampl. Porto Alegre: Livraria do Advogado, 2011.

STRECK, Lenio Luiz. 0 que é isto - decido conforme minha consciência? Porto Alegre: Livraria do Advogado, 2010.

STRECK, Lenio Luiz. Quanto vale o narcisismo judicial? Um centavo? CONJUR, mai. 2012. Seção Senso Incomum. Disponível em: <http: / / www.conjur.com.br/2012-mai-17/senso-incomumquanto-vale-narcisismo-judicial-centavo> Acesso em: 24 abr. 2014.

STRECK, Lenio Luiz. Verdade e Consenso. São Paulo: Saraiva, 2011.

Recebido em: 24.04.2014

Revisões em: 04.06.2014

Aprovado em: 25.07.2014 